In Susan J. Brison and Katharine Gelber (Eds.), Free Speech in the Digital Age (Oxford: Oxford University Press, 2019); https://global.oup.com/academic/product/free-speech-in-the-digital-age-

9780190883607 ?cc $=$ gbElang=enË\#

\title{
Search Engines and Free Speech Coverage
}

\author{
Heather M. Whitney and Robert Mark Simpson ${ }^{\dagger}$
}

\begin{abstract}
This paper investigates whether search engines and other new modes of online communication should be covered by free speech principles. It criticizes the analogical reasoning that contemporary American courts and scholars have used to liken search engines to newspapers, and to extend free speech coverage to them based on that likeness. There are dissimilarities between search engines and newspapers that undermine the key analogy, and also rival analogies that can be drawn which don't recommend free speech protection for search engines. Partly on these bases, we argue that an analogical approach to questions of free speech coverage is of limited use in this context. Credible verdicts about how free speech principles should apply to new modes of online communication require us to re-excavate the normative foundations of free speech. This method for deciding free speech coverage suggests that only a subset of search engine outputs and similar online communication should receive special protection against government regulation.
\end{abstract}

Keywords: free speech, search engines, First Amendment, analogical reasoning

\section{Introduction}

The idea at the heart of liberal political theory is that everyone should be free to live according to their own ideals, so far as this doesn't unduly interfere with other people's ability to do likewise. The government can only legitimately restrict people's freedom where this is necessary to prevent harm to others or secure the demands of justice. The idea at the heart of free speech theory is that when it comes to communicative

\footnotetext{
† Note: this is the final authors' draft. All citations should refer to the final published version, as per the details above. For helpful comments, thanks to the editors, as well as Will Baude, Genevieve Lakier, Richard McAdams, Jim Weinstein, and participants at the 2016 Yale Law School Freedom of Expression Scholars Conference and 2016 Australian Society for Legal Philosophy Conference.
} 
acts, a commitment to individual freedom isn't enough, and must be bolstered by extra protections that make harmful speech less liable to regulation than other similarly harmful conduct.

Because free speech principles assign extra protection to a specially nominated class of communicative acts, they need to come packaged with an account that specifies which communicative acts warrant this protection. Following Frederick Schauer (1982), we call this the question of free speech coverage. Policy outcomes in a system based on free speech principles aren't fully dictated by how we address questions of coverage. (This is because not all conduct that's covered by free speech principles will be immune to regulation, once all relevant factors are considered, including degrees of harm and government interest.) But questions of coverage are important all the same, because stricter standards must be met before acts that are covered by free speech principles can justifiably be regulated.

In this paper we ask whether new modes of online communication should be covered by free speech principles. We'll focus on the outputs of programs that synthesize, organize, and transmit third-party communication to users. Search engine results are the most familiar example of this. Another notable example is Facebook's Trending News section. Whether these things should be covered by free speech is an important problem. The US Supreme Court recently declared cyberspace "the most important place... for the exchange of views" and social media sites "the modern public square." Major tech companies increasingly control our channels of communication and access to information. If search results and the like are specially protected against regulation, this makes it harder for governments and other actors to regulate that control for the sake of goals or ideals that are in the wider public interest. Beside these implications, our question is also a kind of test case for examining the methods employed in debates over free speech coverage. Part of our aim is to show certain limitations in addressing such debates using analogical reasoning.

In \$2-3 we discuss the small body of US case law and related scholarship that deals with this issue. Most discussion in both contexts subscribes to an editorial analogy that likens search results to traditional editorial publications. We find this analogical reasoning tenuous at best. We argue that search engines are unlike traditional editorial publications in several important ways, and that there are other analogical frameworks that offer rival characterizations of the function of search engines, and which suggest different treatment. As for the more general methodological issues, we argue that although analogical inference is often seen as an essential element in common law legal reasoning, at best only certain forms of analogical inference are essential, and the form used by US courts and legal scholars in cases relating to search engines isn't one of them. Building on these critical points, in $\$ \S 4-5$ we argue that credible judgments about whether search engines and the like qualify as "speech" can only be grounded in an account of free speech's normative purposes. We focus on two normative theories of free speech - democratic participation, and Shiffrin's thinker-based approach - and explain why, under either theory, only a subset of search engine results and similar communication should be accorded free speech coverage.

${ }^{1}$ Packingham v. North Carolina, 582 US (2017), 


\section{Recent Cases}

Of the few US courts to address the question of whether search engine outputs qualify as "speech" for free speech purposes, Zhang v. Baidu offers the most thorough analysis. $^{2}$ The facts in Zhang are as follows. The plaintiffs, self-described as "promoters of democracy in China," alleged that Baidu.com (a Chinese search engine) intentionally delisted their pro-democracy websites at the behest of the Chinese government, and that this violated, inter alia, several of their rights. ${ }^{3}$ In reply Baidu argued that its listings were protected speech, and the court agreed, finding that "First Amendment jurisprudence all but compels the conclusion that Plaintiff's suit must be dismissed." ${ }^{4}$ The court saw the relevant precedent as Miami Herald Publishing v. Tornillo, in which a statute forcing newspapers to provide political candidates a right of reply to critical editorials was deemed unconstitutional, on free speech grounds. ${ }^{5}$ The Zhang court also found Hurley v. Irish-American Gay, Lesbian, and Bisexual Group of Boston to be an extension of Tornillo, and equally applicable to Baidu. ${ }^{6}$ In Hurley the Court held that it was a violation of people's free speech rights to legally compel the organizers of a parade to include parties promoting a message they disagreed with, because "a speaker has the autonomy to choose the content of his own message." The Zhang court's application of Tornillo and Hurley followed directly from its analogical reasoning. The court saw the purpose of search engines as organizing information, which requires judgments about what information to include and how to present it, and it found that this was relevantly similar to a "newspaper editor's judgment of which... stories to run."

The editorial analogy also won out in the case of Eventures Worldwide v. Google (Cushing 2017, Goldman 2016, Masnick 2016). ${ }^{9}$ E-ventures is a search engine optimization (or SEO) firm. SEO firms seek to improve the visibility of client websites in organic (i.e. unpaid) search results, in order to increase the client's web traffic from search engines and enable them to sell advertising space at higher rates (DeMers 2016). SEO firms are engaged in an ongoing 'cat-and-mouse game' with search engine companies like Google, because as the firms devise new tactics to improve their client's visibility, Google and co. try to prevent these firms from (as they see it) gaming the system for unpaid rankings. When SEO firms get the upper hand advertisers are more likely to spend their advertising budget with SEO firms, instead of paying Google for paid placement in search results (Tsotsis 2011). In E-ventures specifically,

\footnotetext{
${ }^{2}$ Zhang v. Baidu, 10 F.Supp.3d 433 (S.D.N.Y. 2014).

${ }^{3}$ Id. at 435 .

${ }^{4}$ Id. at 436 .

${ }^{5}$ Id. (citing Miami Herald Publishing Co. v. Tornillo, 418 US 241 (1974)).

${ }^{6}$ Zhang v. Baidu, 10 F.Supp.3d at 437 (citing Hurley v. Irish American Gay, Lesbian, and Bisexual Group of Boston, 515 US 557 (1995)).

${ }^{7}$ Hurley v. Irish American Gay, Lesbian, and Bisexual Group of Boston, 515 US 557, 558 (1995).

${ }^{8}$ Zhang v. Baidu 10 F.Supp.3d at 438.

${ }^{9}$ E-ventures Worldwide v. Google, Inc., 2:14-cv-00646-PAM-CM at 3, 8 (M.D. Fla. Feb. 8, 2017).
} 
Google had manually geared their search results in order to de-list 231 websites belonging to E-ventures's clients. ${ }^{10}$ After reaching out to Google through a number of channels in the hope of getting these sites re-listed, E-ventures filed suit, at which point Google re-listed the sites. In its suit E-ventures alleged that Google's statements about its search results - for instance: "Google search results are a reflection of the content publically available on the web"; and "It is Google's policy not to censor search results" - were false and deceptive. ${ }^{11}$ It also alleged that Google's delisting of its clients' sites constituted unfair competition under the Lanham Act, tortious interference with business relations, and violations of Florida's Deceptive and Unfair Trade Practices Act. Google responded by asserting, inter alia, that E-ventures's claims were overridden by the First Amendment, and that its search results were its editorial judgments and protected opinions.

In originally denying in part Google's Motion to Dismiss, the district court said it had "little quarrel with the cases cited by Google for the proposition that search engine outputs are protected by the First Amendment." 12 The court accepted the editorial analogy in general, but found that "while publishers are entitled to discretion for editorial judgment decisions" in this case the allegation was that such decisions were not the result of editorial judgments but anticompetitive motives. ${ }^{13}$ Additionally, the court noted that facts published maliciously with knowledge of their falsity or serious doubt about their truth can overcome editorial judgment protection. Given these reasons, the court denied in part Google's Motion to Dismiss. However, at Summary Judgment Google's First Amendment arguments proved decisive. There the court cited Baidu for the proposition that search results are protected speech under the First Amendment. ${ }^{14}$ Then, citing Tornillo, it found that a "search engine is akin to a publisher, whose judgments about what to publish and what not to publish are absolutely protected by the First Amendment." ${ }^{15}$ Free speech overrides E-ventures' claims, the court said, because Google's determination of its rankings, and of which sites violated its guidelines and were subject to removal, were "the same as decisions by a newspaper editor regarding... which article belongs on the front page, and which article is unworthy of publication." ${ }^{16}$ In short, the court said that free speech rights should protect such decisions "whether they are fair or unfair, or motivated by profit or altruism." 17

\footnotetext{
10 "De-listing" means the sites were removed from Google's search results such that no subsequent search query would bring up an E-ventures site.

${ }^{11}$ Complaint, E-ventures Worldwide v. Google, Inc., 2:14-cv-00646-JES-CM (M.D. Fla. Nov. 4, 2014).

${ }^{12}$ E-ventures Worldwide v. Google, Case No. 2:14-cv-646-FtM-29CM, 2016 WL 2758889 at 15 (M.D. Fla. May 12, 2016)

${ }^{13}$ Id. at 16.

${ }^{14}$ E-ventures Worldwide v. Google, Inc., 2:14-cv-00646-PAM-CM at 8-9 (M.D. Fla. Feb. 8, 2017).

${ }^{15}$ Id. at 8 .

${ }^{16}$ Id. at 9 (our emphasis).

${ }^{17} \mathrm{Id}$.
} 
The image of the search engine company as editor, with its publication and delisting choices (for paid and organic results alike) viewed as subjective editorial opinion, has been successfully invoked in several other cases as well, ${ }^{18}$ and thus a clear trend has emerged in US legal practice around this issue. Courts treat search engine results and advertisements like editorial judgments and extend free speech coverage to them accordingly.

That said, there are reasons to doubt that these rulings are settled constitutional doctrine. First, the Supreme Court has yet to weigh in on the matter. Second, plaintiffs in these cases were modestly resourced compared to the companies they were opposing (some plaintiffs proceeded pro se). Consequently, the courts were under little pressure to interrogate the cursory analogical rationales that favored the defendants. There may be conflicts involving better-resourced plaintiffs in the future. Indeed, one case like this is already brewing. Yelp and TripAdvisor have argued that Google deliberately diverts users searching for their sites to Google-owned alternatives. Google has said that some such results are due to software bugs, but its competitors have rejected this and lobbied in support of European antitrust investigations against Google (Bergen 2015, Kanter and Scott 2015, European Commission 2015). Given this, it's possible that a major lawsuit in the US - and with it, a vigorous battle over First Amendment coverage - may yet materialize.

\section{The Limits of Analogical Reasoning}

In this section we explain why the analogical reasoning that has guided these cases doesn't offer adequate support for the view that search engine outputs should in fact receive free speech coverage. There are shortcomings with these analogies on their own terms, rival analogical frameworks, and deeper limitations in the use of this form of analogical reasoning.

\subsection{Internal Weaknesses of the Editorial Analogy}

The strongest defence of the editorial analogy invoked in the above cases comes in a white paper commissioned by Google on search engines and free speech, authored by Volokh and Falk (2012). In that paper the authors argue that companies like Google are "analogous to newspapers and book publishers," since they "convey a wide range of information" (Ibid: 27). More specifically, they say editorial publications and search results are alike since they both involve choices about "how to rank and organize content," "what should be presented to users," and "what constitutes useful information" (Ibid: 11).

This is all correct as far as it goes, but it doesn't substantiate the claim that search engines are relevantly similar to editorial publications for purposes of free speech. Consider the layout of a retail outlet like Target. Target selects "content" to present to customers and organizes it to convey information, e.g. using store layouts to promote discounts. If any organization of content to convey information to users is

\footnotetext{
${ }^{18}$ E.g. S. Louis Martin v. Google, Case No. 14-539972 (N.D. Cal. Nov. 13, 2014), Langdon v. Google, 474 F.Supp.2d 622 (D. Del. 2007), Search King Inc. v. Google, 2003 WL 21464568 (W. D. Okla. 2003).
} 
deemed relevantly similar to editing, then store layouts would qualify, ceteris paribus, as speech. But this cannot be right. This way of thinking about the defining characteristics of "speech" transforms the idea that we need to institute additional protections for a special subset of communicative action, into something hopelessly broad. Volokh and Falk may say that the organization of content to convey information only counts as "speech" when it organizes things that are also themselves "speech". But this too is implausible. Whether a newspaper's article ranking the top restaurants in a city qualifies as "speech" doesn't hinge on whether the things being ranked (restaurants) are themselves "speech". Nor will it do to say that it's only in the search engine case that the organization of content conveys a message. Google's message in its search results is that these websites are useful or relevant. But Target's store layout conveys a similar message about its products. In short, organizing things to convey information or judgments of usefulness isn't a function that's distinctive to newspapers and search engines.

Convincing analogies aren't just based on relevant similarities, they're also based on the absence of relevant dissimilarities, so we need to consider how search engines and editorial publications are dissimilar. One difference that has figured prominently in the literature to date is the involvement of algorithms. While editorial publications reflect the conscious choices of specific individuals, search engines use algorithmic processing to index a massive, ever-increasing volume of material, and the staff responsible for them often cannot know what their outputs will be. In Oren Bracha and Frank Pasquale's (2008) terms, search engines produce functional rather than dialogical expression, and thus they're essentially unlike editorial publishing. Against these claims, Volokh and Falk maintain that search engines do in fact incorporate people's judgments, namely, the judgments of staff members who determine how their underlying algorithms will function (2012). Both sides are partially right on this point. Bracha and Pasquale are wrong to suggest that algorithmically-encoded judgments are necessarily functional and not dialogical. At least some dialogical expression can be conveyed via the use of algorithms (Benjamin 2011). And this undermines the claim that algorithmically-mediated speech necessarily lacks the dialogical nature that would make free speech coverage apt. But this is consistent with the plausible view, contra Volokh and Falk, that much algorithmically-mediated communication, including most search results, isn't dialogical, and thus differs from editorial communication.

There are other points of dissimilarity too. Newspapers generally avow their editorial content. By contrast, search engine companies sometimes explicitly disavow the content of their results. Benjamin (2013) describes a case where Google's top result for the term "Jew" was an anti-Semitic site called Jew Watch. When anti-Semitism groups pressured Google to delist the site, Google instead posted a note stating that their results rely on "algorithms using thousands of factors to calculate a page's relevance to a given query" and that they don't reflect "the beliefs and preferences of those who work at Google" (Ibid: 1469). Google thus suggested that it is a mere conduit for others parties' content. Newspapers generally take the opposite stance. In Tornillo, the newspaper was so intimately tied to the content it published that a mere right of reply was thought to compel the newspaper to speak. 
The recent controversy around Facebook's Trending News section (see Nunez 2016, GOP 2016, Oremus 2016, Hunt 2016) sheds further light on the ways companies tactically disavow authorship of the outputs of programs that synthesize and transmit third-party content to users. While this controversy was partly driven by partisan politics, it was also a reaction to the duplicity of Facebook's self-presentation. Facebook styled itself as a neutral conduit of information. It sought to "foster the illusion of a bias-free news ranking process," and it obscured its workers' involvement in curating Trending News content because otherwise it risked "losing its image as a non-partisan player in the media industry", as opposed to an "inherently flawed curator" (Nunez 2016). As with search engine results, this was a context in which the tech company synthesizing and transmitting third-party content was trying to have it both ways: posing as a neutral conduit where taking ownership for the outputs of its programs would be costly, but simultaneously seeking the special legal privileges of editorial speech. ${ }^{19}$ Whatever may be said in defense of this balancing act, the crucial point for our purposes is that this is generally not what editorial publications do, nor how they are perceived by their uses. Whereas users generally believe that search engines "provide open conduits to others' content" (Zittrain 2014), and whereas as users typically don't "associate website content with the search engine that guided the user" (Bracha and Pasquale 2008: 1197), newspaper readers, by contrast, generally regard the newspaper's content as representative of the company's editorial point of view (Spayd 2016).

We should acknowledge that search engines outputs, like editorial publications, come in different forms. Some search engine results are ostensibly paid advertising, and of those that aren't, some are produced by algorithms alone, while others result from the manual gerrymandering of algorithmic outputs. The debate around search engines and free speech coverage should be sensitive to this variety (Ballanco 2013). But recognition of this variety doesn't undermine the critical points we're making about the adequacy of the editorial analogy. Rather, it undermines any across-theboard analogical reasoning that tries to extend free speech coverage to all search engines and the like, based on partial similarities between search engines and newspapers. This analogy is much less compelling than recent First Amendment case law would suggest. The observed similarities that it rests on are overly broad, and there are dissimilarities that the analogy doesn't accommodate.

\footnotetext{
${ }^{19}$ In response to this one might argue that search engines and Facebook newsfeeds cannot ever be purely neutral conduits of content, that they cannot avoid embedding decisions about how to rank and organize content. That's right, but it doesn't follow that free speech protections are warranted for any method a company might use to rank and organize content. Google supports network neutrality rules which prevent internet service providers (ISPs) from blocking or prioritizing content (Brodkin 2015, Benjamin 2011). Google thus endorses regulations that compel other companies to act like the sort of impartial conduits that it and Facebook present themselves as (McKinnon and Kendall 2016). This indicates that, by these companies' own lights, a commitment to free speech is compatible in principle with regulatory controls on companies that purport to supply users with neutral or open access to third-party sources of information and communication. See United States Telecom Ass'n v. Federal Communications Commission, 825 F.3d 674 (D.C. Cir. 2016).
} 


\subsection{Alternative Analogies}

Further to these problems, we can also offer rival analogies that favor the view that search engines shouldn't receive free speech coverage. We'll discuss two such analogies, focusing on search engines and likening them to (i) shopping malls and (ii) fiduciaries.

In Pruneyard Shopping Center v. Robins, the appellees, a group of high school students, set up a stand gathering signatures for a petition in a privately-owned shopping center. ${ }^{20}$ Security guards forced the students to leave, and the students sued, claiming their right to solicit signatures on the premises under the California Constitution. The California Supreme Court ruled in their favor, but the center appealed, claiming a violation under the Federal Constitution of their speech rights, and - like the companies in \$2 - cited Tornillo to argue that they were being compelled to endorse a message they rejected..$^{21}$ The court rejected this argument, finding that the center wasn't compelled to endorse any message, and was free to dissociate itself from the appellees' views. The court also offered an account of the reasoning behind Tornillo. The state can't force newspapers to publish right of reply articles as this would deter editors "from publishing controversial political statements," and thus limit the "vigor" and "variety" of public debate. ${ }^{22}$ That combination of factors didn't obtain in the case of Pruneyard, and so the court rule that appellants' First Amendment rights were not infringed by a state-protected right of expression and petition on their property.

There is an analogy that can be drawn between Pruneyard and Google's search engine results, which has at least some prima facie appeal. Google, like the center, is not literally a newspaper. Google's homepage, like the shopping center, is accessible to the general public. Google, like the center, can and does publicly dissociate itself from views expressed by people who, so to speak, set up a table on their sites. And like in Pruneyard, preventing Google from ejecting (i.e. de-listing) speakers won't do anything to limit the vigor or variety of public debate. If we liken search engines to the center in Pruneyard, a prohibition on delisting speakers and content doesn't look a First Amendment problem after all.

An alternative analogical approach conceives of major tech companies as information fiduciaries (Balkin 2016, Grimmelmann 2014). This is similar to how the court reasoned in imposing the Fairness Doctrine in Red Lion v. Federal Communications Commission, ${ }^{23}$ and it also accords with the Court's recognition in Packingham of cyberspace as "the most important place" for the exchange of views. The law routinely regulates the speech of fiduciary actors like lawyers or doctors, so there is ample case law to support the regulation of the online behavior of tech companies if the general thrust of the analogy holds.

Naturally, as with the editorial analogy, the analogization of search engine results to shopping malls, or of search companies to fiduciaries, requires us to assert the importance of the similarities that the analogies rest on, and to argue that there are no decisive countervailing dissimilarities. Others have discussed some limitations of these

\footnotetext{
${ }^{20}$ Pruneyard Shopping Center v. Robins, 447 US 74 (1980).

${ }^{21}$ Id. at $87-88$.

${ }^{22}$ Id. at 88.

${ }^{23}$ Red Lion v. Federal Communications Commission, 395 US 367 (1969).
} 
rival analogies (Bambauer 2016). The crucial point for our purposes is simply that all three analogies have some prima facie purchase. When it comes to programs that organize, rank, and transmit third-party communication to users, some of what they do is similar, in some respects, to some of what publishers or editors do, some of what they do is similar, in some respects, to some fiduciary services, and some of their functions are similar, in some respects, to the function of general public spaces in shopping malls. The question that everything hinges on is: which similarities and dissimilarities are the ones that matter from the point of view of free speech principles? In the First Amendment context, to invoke compelled speech doctrine and cite Tornillo as the relevant precedent - simply based on the mere fact that both search engines and newspapers rank and organize content - is to beg this question, instead of properly addressing it. In asking which similarities and dissimilarities matter from the perspective of free speech principles, we are posing a question whose answer cannot but reside in normative considerations. Analogical methods that respond to questions of free speech coverage by noting similarities between different types of communication, but without examining these underlying normative concerns, are at best limited and at worst misleading.

\subsection{The Limits of Analogical Reasoning}

The utility of analogical reasoning in law is contested, with some finding it to be the "cornerstone of common law reasoning" and others seeing it as "mere window-dressing, without normative force" (Lamond 2014; see also, Sunstein 1992, Alexander 1996, Sherwin 1999, Posner 2008, Alexander and Sherwin 2008, Lamond 2014). Our view is that, while there are reasons to reject the use of analogical reasoning in particular contexts, it doesn't make sense to either endorse or reject analogical legal reasoning wholesale. In short, some forms of analogical reasoning are illuminating in some legal contexts, but the analogical reasoning used in debates about search engines free speech coverage isn't such a case.

Grant Lamond (2014) distinguishes three types of analogies in legal reasoning: Classificatory, Close, and Distant. Classificatory Analogies are based on similarities between the facts of the two cases and are used to help determine the legal characterizations of those facts. Close Analogies help to settle novel legal issues raised by a case where there is no directly applicable legal authority. Judges identify a related case and consider whether the rationale that underlies its resolution is applicable to the one before it. Lamond gives the example of $D v$. NSPCC, in which the plaintiff sought to force a private charity to disclose the identity of its informant. Settled law had it that the police couldn't be forced to disclose informants' identities, but no law spoke to compelling a private charity vested with statutory power to disclose its informants. The House of Lords saw a Close Analogy in the offing. It looked at the law governing compelled disclosure of police informants, and concluded that the reasons behind the non-disclosure immunity were equally applicable to charities. Close Analogies are thus tools that help courts uncover the reasons that should guide them when no directly applicable authority is available. The analogy as such does little work.

Lamond's third category is Distant Analogies, which differ from Close Analogies by matter of degree. Like Close Analogies, Distant Analogies are raised when there is no binding authority. The difference is how far afield courts must look to find 
helpful cases. Lamond gives the example of the development of oil and gas rights in the United States. The novel question courts faced was whether land owners had property rights to oil or gas reservoirs that lay underneath their land. Early American courts were "captured" by the law of capture analogy. But as Posner (2008) points out, courts in the grip of this analogy failed to see the relevant dissimilarities between the cases. The identification of the purportedly relevant-yet-distant case is also "haphazard," which increases the risk that a court will not have "all possible (and possibly conflicting) analogies before it" (Lamond 2014: 583). And partly as a consequence of this haphazardness, prior cases are more likely to be invoked without adequate consideration of the reasons that underpinned the original judgment.

With these three types of analogical reasoning distinguished, we are faced with our own classificatory puzzle: where to place the analogical reasoning used in the search engine cases. In light of the points already discussed, we believe this to be an instance of Distant analogical reasoning. Although there are prima facie similarities between search engines and traditional editorial publications, there are also prima facie similarities between search engines and other kinds of entities, and this is the result of the fact that they are complex entities, which do not neatly correspond with any of our preexisting categories of communicative practice. Whether search engine results and similar forms of communication qualify as "speech" for the purposes of free speech principles is a genuinely novel and genuinely difficult question. To reiterate our earlier point, when analogical reasoning is brought in to try to address this question, everything then hinges on our judgments about which similarities really matter from the point of view of free speech. And this question forces us to reflect on the deeper aims or ideals that underpin free speech principles, and how those aims or ideals would be affected by expanding the scope of free speech to encompass search engines.

\section{The Stakes of Coverage}

To see how different normative concerns are implicated in a debate over free speech coverage, we need to clarify what practical consequences hinge on the debate. And in the questions of coverage that we're examining here, this is (unsurprisingly) complicated. The types of communication that we're consider are relatively new and still evolving. Their functions now and their functions in the future may be different. But some insight is possible nonetheless. We approach the question of the stakes by considering some results that may ensue depending on whether free speech protections are extended to these entities.

Let's start by considering some implications for business practices. If search engines are covered by the First Amendment in the US it will be easier for them to bury their competitors' websites without fear of consumer protection or unfair competition lawsuits. Note that Google seeks free speech protection for its search results for this very reason. For instance, in its briefs in KinderStart.com, Google argued that "because 
the actions on which KinderStart premises liability are protected by the First Amendment, they certainly cannot be "unfair' under the UCL [Unfair Competition Law]." 24 Google used similar arguments in E-Ventures. ${ }^{25}$ Note also that the court's response in E-Ventures suggests that how questions of coverage are decided may not fully dictate how unfair competition law applies. The court found Google's results to be fully protected opinion, but it said Google could be liable for anticompetitive conduct nevertheless if its claims about why it delisted the plaintiff's site were found to be untrue. It's also notable that the California Attorney General's office has looked for ways to expose Google's search results around shopping to antitrust scrutiny, consistently with these results being covered by First Amendment doctrine (Gibson 2014). These developments indicate that free speech coverage wouldn't necessarily result in full immunity from regulation or liability in this space. However, it's compatible with all this to recognize that the characterization of search engines and the like as protected speech, all things considered, would be a significant strategic victory for these companies.

Complex political implications might also hinge on how questions of coverage are resolved. The most obvious concern is that failure to grant free speech coverage to search engines and the like will allow the state to use its regulatory powers to enact a repressive political agenda. Governments in many parts of the world already do this (Goldsmith and Wu 2006, MacKinnon 2012). In the US one might worry that an authoritarian President could use regulatory codes as a way to pressure online companies to obstruct access to political dissent (Bambauer 2012, Bambauer 2015). Where such fears are overtly tied to questions of free speech coverage, however, they should be tempered by a recognition that actions in this vein can be and have been struck down on First Amendment grounds even in cases in which they haven't been deemed to infringe the free speech rights of distributors. ${ }^{26}$ The withholding of coverage might be a more determinative factor if governments are trying to compel companies to include, rather than remove, content. For instance, if a state wanted specific health advice to be prominently displayed, and if First Amendment constraints were out of the picture, then legislation compelling this would quite probably pass constitutional muster, provided the government didn't exact unconstitutional Takings.

In sum, just looking at the US context, there are certain areas where non-coverage could enable states to regulate sites that organize and transmit third-party content, and other areas where this would have minimal impact. It isn't unreasonable to worry about how, without special protection for online programs, liberal states might be susceptible to authoritarian repression. But these fears shouldn't downplay the ways in which anti-authoritarian ideals are already solidly embedded in protections for the individuals using these sites. Commitment to a free press is generally compatible with the state imposing various forms of regulatory oversight on ISPs that mediate communication and the flow of data. The differences in how these organizations and types of

\footnotetext{
${ }^{24}$ Kinderstart.com, LLC v. Google Inc. 2006 WL 1786956 (N.D. Cal., filed May 2, 2006) (defendants notice of motion and motion to dismiss the first amended complaint; memorandum of points and authorities).

${ }^{25}$ E-Ventures Worldwide, LLC v. Google, Inc., No. 2:14-CV-646-FTM-29CM, 2016 WL 2758889 (M.D. Fla. May 12, 2016), reconsideration denied, No. 2:14-CV-646-FTM-29CM, 2016 WL 4409338 (M.D. Fla. Aug. 19, 2016), and motion to certify appeal denied, No. 2:14-CV-646-FTM-29CM, 2016 WL 4409339 (M.D. Fla. Aug. 19, 2016).

${ }^{26}$ E.g. Bantam Books, Inc. v. Sullivan, 372 US 58 (1963).
} 
content are liable to regulation owes to differences in the kinds of work they do, and the social functions they fulfill. So while it's prudent to worry about government overreach, it's also reasonable, given the increasing social dominance of the tech sector, to worry about tech companies using their market power to advance their own interests at the expense of the public interest.

\section{Normative Theories of Free Speech}

Against this mostly descriptive backdrop we're now in a position to ask whether search engine outputs should receive free speech coverage in view of the normative purposes of free speech principles. This of course requires us to specify what our reasons are for protecting a privileged subset of communicative activities in the first place. In what follows we'll work through the question of coverage for online programs that rank and organize content, using two prominent normative theories of free speech as reference points, namely, the democratic participation theory and Seana Shiffrin's thinker-based theory.

Democratic ideals are invoked by a number of influential First Amendment scholars to explain and defend US free speech doctrine (e.g. Meiklejohn 1948, Post 1990). Building on this tradition, the democratic participation theory of free speech says that speech must be protected in order to ensure "the opportunity for individuals to participate in the speech by which we govern ourselves" (Weinstein 2011: 491). How do we decide what counts as "speech" using democratic participation as our normative reference-point? We cannot construe the ideal too broadly, such that all parts of social life are seen as a part of the project of self-government, since in encompassing everything the ideal would prioritize nothing. Instead, the ideal of democratic participation requires us to divide society into two domains: public life, where we act as citizens cooperating in collective self-governance, and private life, where we act independently in the service of our own projects. For free speech principles grounded in democratic participation, "speech" denotes whatever forms of communication are integral to collective self-governance. Of course there will be complications at the margins, but the implications of the democratic participation theory are discernible all the same. Free speech principles aren't meant to immunize all communication against legitimate regulatory aims. They're meant to support the project of collective self-government, by safeguarding the communicative conduct essential to that project's realization.

With those clarifications in place, the pertinent question for our purposes is whether the outputs of online programs that organize, synthesize, and transmit thirdparty communication to users, are integral to democratic self-governance? We gain a useful perspective on this by seeing how proponents of this theory of free speech assess questions of coverage in other areas. One prominent advocate of a democratic participation theory of the First Amendment spells out the theory's implications for questions of coverage as follows.

When allegedly defamatory speech concerns a public official, stringent First Amendment protection applies... But if the speech addresses a purely private concern, then no First Amendment limitations restrain the normal operation of defamation law... A lawyer has a First Amendment right to solicit clients when 
"seeking to further political and ideological goals" through litigation, but not for ordinary economic reasons (Weinstein 2011: 494).

For each of these pairs we see that communication primarily related to matters of public interest is covered by free speech, but communication primarily related to economic and personal matters isn't. And notice that there's no requirement - in the theory, or in the doctrine it explains - that all instances of a communication-type get the same coverage.

Now consider search engines. From one perspective they're commercial entities plain and simple. They organize content in a way that's enmeshed with the commercial practices of companies, they mediate people's access to sites of online commerce, and in these services they constitute a commercial enterprise of their own, built around advertising sales and data acquisition. But of course they aren't wholly commercial. Search engines also fulfill important communicative functions related to matters of political concern, e.g. by mediating access to information and opinions created by third-party speakers. As explained in $\$ 4$, questions of coverage could have implications for tech industry practices on both commercial and political fronts. On top of all this we should also note that search engines facilitate much in the way of purely private communication, e.g. by making things like personal blogs accessible to readers. In view of this diversity, the most reasonable way to set the scope free speech coverage, under the democratic participation theory, would be to mirror this diversity by saying that search engines are covered by free speech principles in their functions related to matters of political concern, but not where they're primarily carrying out commercial functions or facilitating private communication. In relation to cases like E-Ventures, or in relation to skirmishes between companies like Google and Yelp, the main upshot of withholding universal free speech coverage from search engines would be that anticompetitive practices within this domain lose any de facto immunities against unfair competition laws. Assuming a reasonable interpretation of the democratic participation theory of free speech, it would be a mistake be oppose that conclusion on free speech grounds. And this is a mistake that existing First Amendment doctrine makes it relatively easy to avoid, simply by drawing distinctions like those that Weinstein mentions, which allow us to square the protection of political defamation with the restriction of private defamation. ${ }^{27}$

We'll keep our discussion of a second normative theory of free speech brief, as our points structurally resemble our remarks about the participatory democracy theory. The 'thinker-based' theory of free speech, recently developed by Shiffrin, identifies "the individual agent's interest in the protection of the free development and operation of her mind" as its normative keystone (Shiffrin 2011: 287, 2014). ${ }^{28}$ Whereas

\footnotetext{
${ }^{27}$ In contemporary US constitutional law an appeal to expansive interpretations of free speech to strike down commercial and economic regulation isn't unusual. It's a development - sometimes called 'the Lochnerization of the First Amendment' - that's occurred on many fronts (Wu 2013, Kendrick 2015, Shanor 2016).

${ }^{28}$ The antecedents of her theory in the free speech literature are diverse. Her emphasis on the individual's selfrealization as an end in itself is reminiscent of certain themes from Mill (1859). Her theory characterizes the individual thinker as one who bears responsibility for her mental life, which is an idea stressed in influential work by Thomas Scanlon (1972) and David Strauss (1991). And the articulation of the interests of "the thinker" relating to expressive liberties is a part of Joshua Cohen's (1993) work on free speech, although it
} 
other theories situate the value of the thinker in relation to extrinsic ideals or desiderata, Shiffrin's theory identifies a direct and non-contingent link between the value of mental autonomy and the justification for the protected status of communicative conduct. Again, however, not all communication is privileged under such a theory. If we prioritize the "fundamental function of allowing an agent to transmit... the contents of her mind to others and to externalize her mental content" (Shiffrin 2011: 295), then we'll need to have special protections for people expressing their thoughts on any matter under the sun. This is part of what makes Shiffrin's theory distinctive: the expression of thoughts about politics and government doesn't occupy an exalted position relative to the expression of thoughts about everyday life. But crucially, what is specially protected on this theory isn't communication as such, but the communication of the thought of individuals. And this will tend to assign a less privileged status to much commercial communication. So when we revisit our key question - whether programs that synthesize and transmit third-party communication to users are implicated in 'the fundamental function of allowing an agent to transmit the contents of her mind to others' (Ibid: 295) - the diagnosis is mixed, as in the previous case. One interesting consequence of the thinker-based theory is that, unlike the democratic participation theory, it suggests that facilitation of everyday online chatter by search engines and social networks may be as much a part of the case for protecting (some of) their operations as their role in facilitating political discourse. But as with the democratic participation theory, much of what these programs do - and in particular, their functions that are primarily commercial in nature - will likely fall outside the scope of free speech coverage by the lights of this normative theory.

\section{Conclusion: Similarity, Coverage, and Expansion}

Nelson Goodman (1972) regarded 'similarity' as a near-useless concept. For any pair of things we can find some resemblance or shared feature, in view of which we can say that the things are in some sense alike. In most everyday settings Goodman's skepticism sounds over-the-top. If you pick up an apple that's the same color and complexion as the rotten one you bit into earlier, you do well to throw it away. Judgments based on observed similarity are, likewise, part of the law's everyday business. If a publisher launches a periodical printed in purple ink, the judge needn't re-excavate the normative grounds of press freedom and compelled speech doctrine before deciding that a purple-ink paper merits the same protection as normal black-ink papers. The differences reside in peripheral and accidental properties, not central and essential ones. But as judgments of this sort progress along a spectrum in the comparisons they're dealing with - from simple to complex entities, from low-stakes to high-stakes decisions - the force of Goodman's skepticism becomes evident, and we lose confidence in saying which of a thing's properties are the ones that matter.

Or we should, at any rate. In debates over search engines and free speech coverage, neither the gravity of the policy stakes, nor the complexity of the things being compared, has dampened the willingness of courts and scholars to use tenuous analogies in charting the way forward. Everyone can agree that search engines and the like

merely one element among others. Bambauer (2014) also endorses a version of this theory, arguing for a thinker-centered First Amendment and corollary right to learn new things. 
should be covered by principles of a free press, if and to the extent that they occupy a similar cultural position to the press (Tutt 2012). The point is that casual analogical methods - observing that both types of things "convey a wide range of information" or "rank and organize content" - don't tell us whether these things are similarly culturally-positioned in the ways that matter, given the ideals underlying the principles whose scope of application we're trying to decide. The only way to answer that question is to articulate what the consequences are likely to be if we do or don't extend free speech coverage (\$4), to review our most appealing or credible accounts of the underlying aims or purposes which are in play (\$5), and then to extend coverage where the likely consequences of doing so support the relevant aims. In applying this method we find that, contrary to the currently-prevailing view, only a subset of search engine results and similar communication should receive free speech coverage.

The problems with analogical methods for addressing questions around free speech coverage aren't peculiar to the specific debate that we've examined. In recent American free speech jurisprudence there has been steady outward pressure on the scope of free speech coverage. This is partly because novel arguments that drive in this direction have a recent track-record as a winning strategy (Schauer 2015). ${ }^{29}$ It may also reflect some sort of predilection in the underlying architecture of categorical legal rules, which in borderline cases tilts the scales in favor of encompassing a case under the rule rather than excluding it (Kendrick 2015). Regardless of what's driving the expansion of free speech coverage, it runs the risk of changing free speech from a precision instrument that warrants the support of liberals of all stripes, into a blunt deregulatory cudgel that only appeals to strident anti-government types. Simple analogical approaches to questions of free speech coverage, which pay no attention to free speech's normative foundations, assist in that transformation. An approach to free speech coverage that's focused on normative theories of free speech won't deliver tidy verdicts about where and how free speech principles should apply. But all the same, it's one way to keep free speech coverage from expanding past the point of credibility.

\section{References}

Alexander, L. and Sherwin, E. 2008. Demystifying Legal Reasoning. Cambridge: Cambridge University Press.

Alexander, L. 1996. Bad beginnings, University of Pennsylvania Law Review 145: 57-87.

Balkin, J. 2016. Information Fiduciaries and the First Amendment, University of California Davis Law Review 49 (4): 1183-234.

Ballanco, M. 2013. Comment: Searching for the First Amendment: An Inquisitive Free Speech Approach to Search Engine Rankings, George Mason University Civil Rights Law Journal 24 (1): 89111.

Bambauer, J. 2014. Is Data Speech?, Stanford Law Review 66 (1): 57-120.

Response: The Relationship between Speech and Conduct, University of California Davis Law Review 49( 4): 1941-53.

\footnotetext{
${ }^{29}$ Although as our discussion of Pruneyard in $\$ 3.2$ shows, attempts to aggressively broaden the boundaries of what qualifies as "speech" needn't always succeed.
} 
Bambauer, D. 2012. Orwell's Armchair, The University of Chicago Law Review 79 (3): 863-944.

2015. Against Jawboning, Minnesota Law Review 100 (1): 51-126.

Benjamin, S. 2013. Algorithms and speech, University of Pennsylvania Law Review 161 (6): 1445-94.

2011. Transmitting, editing, and communicating: determining what 'the freedom of speech' encompasses, Duke Law Journal 60(8): 1673-1713.

Bergen, M. 2015. Google says local search results that buried rivals Yelp, TripAdvisor is just a bug, Re/Code, November 24, 2015.

Bracha, O. and Pasquale, F. 2008. Federal Search Commission? Access, fairness and accountability in the law of search, Cornell Law Review 93 (6): 1149-1209.

Braddon-Mitchell, D. and West, C. 2004. What is Free Speech?, Journal of Political Philosophy 12 (4): 437-60.

Brodkin, J. 2015. How Net Neutrality Violates the First Amendment (According to one ISP): Broadband Providers Exercise 'Editorial Discretion' over Internet, ISP Says, Ars Technica, October 6, 2015.

Cohen, J. 1993. Freedom of Expression, Philosophy Ė Public Affairs 22 (3): 207-63.

Cushing, T. 2017. Court says Google has a First Amendment right to delist competitors, TechDirt, February 17, 2017.

DeMers, J. 2016. The SEO industry is worth $\$ 65$ billion; will it ever stop growing?, Search Engine Land, May 9, 2016.

European Commission Memo. 2015. Antitrust: Commission sends statement of objections to Google on Comparison Shopping Service, Case No. 39740, April 15, 2015.

Gibson, P. 2014. Does the First Amendment Immunize Google's Search Engine Search Results from Government Antitrust Scrutiny?, Competition: Journal of Antitrust $\mathcal{E}$ Unfair Competition Law, State Bar of California, 23 (1): 125-41.

Goldman, E. 2016. Google must answer lawsuit for manually removing websites from its search results, Forbes, May 17, 2016.

Goldsmith, J. and Wu, T. 2006. Who Controls the Internet? Illusions of a Borderless World. Oxford: Oxford University Press.

Goodman, N. 1972. Seven Strictures on Similarity, in Problems and Projects. New York: Bobbs-Merrill Company: 22-32.

GOP. 2016. \#MakeThisTrend: Facebook Must Answer for Conservative Censorship, GOP website, May 9, 2016.

Grimmelmann, J. 2014. Speech Engines, Minnesota Law Review 98 (3): 868-952.

Hung, E. 2016. Facebook to Change Trending Topics after Investigation into Bias Claims”, The Guardian, May 23, 2016.

Kanter, J. and Scott, M. 2015, European challenges Google, seeing violations of its antitrust laws, New York Times, April 15, 2015.

Kendrick, L. 2015. First Amendment Expansionism, William Ë Mary Law Review 56 (4): 1199-1219.

Lamond, G. 2014. Analogical Reasoning in the Common Law, Oxford Journal of Legal Studies 34 (3): 567-588.

MacKinnon, R. 2012. Consent of the Networked: The Worldwide Struggle for Internet Freedom. New York: Basic Books. 
Masnick, M. 2016. Court says Google doesn't have a First Amendment right to drop a site from its search results, TechDirt, May 20, 2016.

McKinnon, J. and Kendall, B. 2016. FCC's net-neutrality rules upheld by appeals court, Wall Street Journal, June 14, 2016.

Meiklejohn, A. 1948. Free Speech and its Relation to Self-Government. New York: Harper \& Brothers.

Mill, J.S. 1859. On Liberty. (Republished London: Penguin Books, 1985).

Nunez, M. 2016. Former Facebook Workers: We Routinely Suppressed Conservative News, Gizmodo, May 9, 2016.

Oremus, W. 2016. What the Facebook 'Liberal Bias' Controversy is Really About, Slate, May 17, 2016.

Posner, R. 2008. How Judges Think. Cambridge, MA: Harvard University Press.

Post, R. 1990. The Constitutional Conception of Public Discourse: Outrageous Opinion, Democratic Deliberation, and Hustler Magazine v. Falwell,, Harvard Law Review 103 (3): 601-86.

Richards, N. 2015. Why Data Privacy Law is (Mostly) Constitutional, William E Mary Law Review 56(4) (2015): 1501-33.

Scanlon, T. 1972. A Theory of Freedom of Expression, Philosophy EO Public Affairs 1 (2): 204-26

Schauer, F. 1982. Free Speech: A Philosophical Inquiry. Cambridge: Cambridge University Press.

2015. The politics and incentives of First Amendment coverage, William $\mathcal{E}$ Mary Law Re view 56 (4): 1613-36.

Shanor, A. 2016. The New Lochner, Wisconsin Law Review 2016(1): 133-208

Sherwin, E. 1999. A defense of analogical reasoning in law, University of Chicago Law Review 66: $1179-1197$.

Shiffrin, S. V. 2011. A Thinker-based Approach to Freedom of Speech, Constitutional Commentary 27 (2): $283-307$.

2014. Speech Matters: On Lying, Morality, and the Law. Princeton: Princeton University Press.

Strauss, D.A. 1991. Persuasion, Autonomy, and Freedom of Expression, Columbia Law Review 91 (2): 334-71.

Sunstein, C. 1992. On analogical reasoning, Harvard Law Review 106 (3): 741-791.

Tsotsis, A. 2011. Google's algorithmic cat and mouse game [infographic], TechCrunch, March 23, 2011.

Tutt, A. 2012. Software Speech, Stanford Law Review 65: 73-78.

Volokh, E. and Falk, D. M. 2012. First Amendment Protection for Search Engine Search Results, White Paper, April 20, 2012.

Wagner, K. 2015. How Facebook decides what's trending, Re/code, Aug. 21, 2015.

Weinstein, J. 2011. Participatory Democracy as the Central Value of American Free Speech Doctrine, Virginia Law Review 97 (3): 491-514.

Wu, T. 2013. Machine speech, University of Pennsylvania Law Review 161 (6): 1495-1533.

Zittrain, J. 2014. Facebook Could Decide an Election without Anyone Ever Finding Out, The New Republic, June 1, 2014. 